\title{
Wheat gluten/montmorillonite biocomposites: Effect of pH on the mechanical properties and clay dispersion
}

\author{
E. Cortés-Triviño, I. Martínez*
}

Dpto. Ingeniería Química, Centro de Investigación en Tecnología de Productos y Procesos Químicos (Pro2TecS) Campus de Excelencia Internacional Agroalimentario, ceiA3, Universidad de Huelva, Campus El Carmen, 21071 Huelva, Spain

Received 1 December 2017; accepted in revised form 12 February 2018

\begin{abstract}
The addition of inorganic fillers into a bioplastic could increase its mechanical properties, which will be influenced strongly by the type of the clay dispersion. In this work, we have used montmorillonite nanoclays (MMT) to prepare biocomposites by means of an extrusion process. We present herein the effect of the $\mathrm{pH}$ and the addition of montmorillonite nanoclays (MMT) on the barrier and mechanical properties of wheat gluten based bioplastics. The $\mathrm{pH}$ of the samples was modified by adding aqueous solution of a strong acid or base $\left(\mathrm{H}_{2} \mathrm{SO}_{4}\right.$ and $\left.\mathrm{NaOH}\right)$. Tensile, dynamic mechanical thermal analysis (DMTA), water absorption and X-ray tests were carried out to study the influence of the above-mentioned variables on the physicochemical properties and rheological behaviour of bioplastics and biocomposites obtained. Tensile results showed that both Young's modulus and tensile strength are higher at unmodified pH. However, the addition of MMT to an alkaline biopolymer matrix produced remarkable improvements in the rheological and mechanical properties because of a high exfoliation of the nanoclay noticeable in X-ray results. To summarise, extrusion process and the use of nanoclays present an excellent opportunity to develop wheat gluten bioplastics able to replace conventional products.
\end{abstract}

Keywords: nanocomposites, extrusion, wheat gluten, montmorillonite, $p H$

\section{Introduction}

Nowadays, a great interest in the development of new biodegradable polymeric materials from agricultural resources to substitute synthetic polymer has become an important challenge due to an awareness of the environmental impact of conventional plastics. One of those renewable resources is wheat gluten (WG), a by-product of the starch industry with a high protein content $(>75 \mathrm{wt} \%)$. Gluten proteins possess remarkable biodegradability $[1,2]$ and good thermoplastic properties and processability by extrusion [3], making them of interest for packaging and agricultural applications $[4,5]$. Moreover, the use of protein as raw material proffers the formation of diverse polymer network structures via the wide spectrum of chemical functionalities available on the large variety of amino acids [6].

However, a downside to the use of plant-based protein material is that their inherent properties are inferior to those of petrochemical based systems. In addition to introducing chemical diversity, structure modifications of the amino acid functional groups through physical (temperature, pressure) and chemical (cross-linking) methods is a very powerful and versatile tool to tailor protein properties such as water resistance and mechanical performance [7-9]. Another exciting strategy to enhance and introduce the innovative features needed for more demanding and specialized applications is to add certain types of nanoparticles into the polymer matrix, obtaining

${ }^{*}$ Corresponding author, e-mail: imgarcia@uhu.es

(C) BME-PT 
bio-based composite materials, also known as biocomposites [10].

Biocomposites, a new type of material formed by the combination of a natural polymer and an inorganic solid with at least one dimension in the nanometer scale, have drawn the attention of many researches [11-15]. The introduction of nanoreinforcements into the polymeric matrix of biodegradable polymers could be an exciting new advance in the development of eco-friendly biocomposites since their chemical structures provide significant improvements in the barrier, mechanical and thermal properties which can overcome the typical failure of hydrophilic biopolymers films [12, 16-18]. The most popular nanoscale filler consists of nanoclays with layered silicate structure, such as montmorillonite (MMT) and kaolinite, where a central alumina octahedral sheet is located between two silica tetrahedral sheets $[12,19]$. However, to observe these effects it is necessary to achieve a proper dispersion of nanoparticles throughout the polymer matrix [20]. This is often the main challenge in obtaining suitable biocomposite materials [10].

In this study, an alternative means to enhance the nanoclay dispersion in the gluten protein matrix by extrusion based on the use of $\mathrm{pH}$ modifiers was proposed. It is known that the $\mathrm{pH}$ value of the proteins is an important factor for their functional properties [21]. This is due to the fact that proteins change their net charge at a $\mathrm{pH}$ value that is different to their isoelectric point. There is a positive net charge at a lower $\mathrm{pH}$ value and a negative net charge at a higher $\mathrm{pH}$ value [22]. In wheat gluten films, intermolecular interactions such as disulfide bridges, hydrogen bonds, and hydrophobic interactions are especially influenced by a pH shift [23]. Thus, the conformation of the protein in the biocomposite and the relevant interactions between clay and protein are the key to understand the particular properties of biocomposites. So far, the information concerning the effect of $\mathrm{pH}$ on the properties and dispersion of nanoclay of bioplastics produced from wheat gluten protein through extrusion and compression moulding processes is scarce.

With this approach, this work explores the possibility of using plasticized wheat gluten for the development of biodegradable plastics materials. The effect of $\mathrm{pH}$ on the properties of wheat gluten bioplastics and wheat gluten/montmorillonite (WG/MMT) biocomposite prepared by extrusion and compression molding process are presented. The systems were characterized in terms of their tensile properties, water uptake, and thermomechanical properties. The $\mathrm{pH}$ effect on dispersion nanoclay in the protein matrix, morphology and mechanical performance of the materials was discussed. Their structures were determined by X-ray diffraction and transmission electron microscopy as well.

\section{Experimental}

\subsection{Materials}

Commercial vital wheat gluten (WG, with $83 \mathrm{wt} \%$ protein, $8 \mathrm{wt} \%$ moisture and $1 \mathrm{wt} \%$ ashes) was purchased from Brenntag Quimica S.A. (Barcelona, Spain). A mixture of glycerol (G) (Guinama, Valencia, Spain) and distilled water (W) was used as plasticizer. Furthermore, sodium hydroxide (SH) (SigmaAldrich, Madrid, Spain) and sulfuric acid (SA) (Panreac Quimica Sau, Barcelona, Spain) as additive were added to the plasticizer to modify the $\mathrm{pH}$ of the end product. Lastly, a natural montmorillonite (MMT), Cloisite ${ }^{\circledR} \mathrm{Na}^{+}$, from Southern Clay Products (Gonzales, USA) as nanoparticle was used.

\subsection{Sample formulation}

All formulations prepared are collected in Table 1. A total of six systems were considered to study the effect of the $\mathrm{pH}$ and nanoclays on the obtained bioplastics and biocomposites properties. The $\mathrm{pH}$ of the systems was appropriately adjusted with $\mathrm{H}_{2} \mathrm{SO}_{4}$ $(0.2 \mathrm{M})$ and $\mathrm{NaOH}(0.6 \mathrm{M})$ aqueous/glycerol solution. Samples with $(1 \mathrm{wt} \%)$ and without nanoclays were prepared at acid (5.4), unmodified (6.1), and basic (10.8) $\mathrm{pH}$, and were designed as shown in Table 1. Control WGGW bioplastic without nanoclays was prepared at the unmodified $\mathrm{pH}$. The plasticizer consisted of a blend of glycerol $(\mathrm{G})$ and distilled water (W) at $50 \mathrm{wt} \%$. A protein/plasticizer weight ratio of $55 / 45$ and $1 \mathrm{wt} \%$ of clays was maintained, except for the acid system (at $5.4 \mathrm{pH}$ ) where the ratio was modified to $65 / 35$ in order to make the bioplastics processable (a soft and sticky yellowish mass was obtained through die extruder when the WGGW control system was processed with a protein/plasticizer weight ratio of 55/45).

\subsection{Thermoplastic processing}

A co-rotating twin screw extruder with ten differentiated zones (EuroLab $16 \mathrm{~mm}$, ThermoFisher Scientific, Massachusetts, USA) equipped with a circular 
Table 1. Composition of bioplastics and nanobiocomposites investigated.

\begin{tabular}{|l|c|c|r|}
\hline \multicolumn{1}{|c|}{ Sample code } & $\begin{array}{c}\text { Weight ratio } \\
\text { WG/G/W }\end{array}$ & $\begin{array}{c}\text { Cloisite }^{\circledR} \mathbf{~ N a}^{+} \\
\text {[wt\% based on total] }\end{array}$ & pH \\
\hline WGGW & $55 / 22.5 / 22.5$ & & 6.1 \\
\hline WGGW-MMT & $55 / 22.5 / 22.5$ & 1 & 6.1 \\
\hline WGGW-SH & $55 / 22.5 / 22.5$ & & 10.8 \\
\hline WGGW-SH-MMT & $55 / 22.5 / 22.5$ & 1 & 10.8 \\
\hline WGGW-SA & $65 / 17.5 / 17.5$ & & 5.4 \\
\hline WGGW-SA-MMT & $65 / 17.5 / 17.5$ & 1 & 5.4 \\
\hline
\end{tabular}

die of $4 \mathrm{~mm}$ was used to extrude the bioplastics. Wheat gluten was introduced by using a twin screw volumetric feeder (Coperion K-Tron, compact $\mathrm{KC}$, Switzerland), while the plasticizer and additives were added with the aid of a feeder pump. All samples were processed at a constant rotational speed of $100 \mathrm{rpm}$ and with a specific set barrel temperature profile (50-55-50-45-45-45-40-35-30-30 ${ }^{\circ} \mathrm{C}$ from hopper to die). Extruded samples were pelletized by using a Haake FLP 16 granulator (Thermo Scientific, Massachusetts, USA). In addition, nanoclays were easily added to the polymer matrix with the aid of the volumetric feeder, which were previously mixed with the wheat gluten, becoming a good alternative to process biocomposites. The $\mathrm{pH}$ and the visual appearance of samples after extrusion are collected in Table 1.

Afterwards, the pellets were moulded by compressing with a 25T hot plate press (MTI Corporation, Richmond, USA) at $120^{\circ} \mathrm{C}$ and 100 bar gauge pressure for $12 \mathrm{~min}$, by using a rectangular mould of $220 \times 50 \times 3 \mathrm{~mm}^{3}$. Test specimens for tensile tests according to ASTM D638 and $50 \times 10 \times 3 \mathrm{~mm}^{3}$ rectangular specimens for thermal analysis were prepared by means of a die cutting machine (ATS Faar, S.p.A, Milano, Italy). All samples were stored at $53 \% R H$ and at room temperature.

\subsection{Characterization}

\subsection{1. pH measurements}

The $\mathrm{pH}$ values of the samples were determined on die of extruder with a $\mathrm{pH}$ meter equipped with an electrode for solid substances (50 33, Crison Instrument S.A., Barcelona, Spain).

\subsubsection{Tensile tests}

Tensile tests were carried out by using a Shimadzu AG-IS testing machine (Shimadzu Corporation,
Kyoto, Japan) with a $1 \mathrm{kN}$ load-cell in accordance with ASTM D638-10 Standard Test Method for Tensile Properties of Plastics. IV-type dumbbell-shaped specimens $(6 \pm 0.5,33 \pm 0.5$ and $2 \pm 0.5 \mathrm{~mm}$ of width, length and thickener of narrow section, respectively) were tested at a single cycle of $50 \mathrm{~mm} / \mathrm{min}$ and Young's modulus, tensile strength and strain at break were determined for all samples.

\subsubsection{Dynamic mechanical thermal analysis}

\section{(DMTA)}

DMTA tests were performed with a Physica MCR 301 controlled-stress rheometer (Anton Paar, Graz, Austria) equipped with a SRF12 sensor in torsion mode. Storage $\left(G^{\prime}\right.$ and loss $\left(G^{\prime \prime}\right)$ moduli were obtained as a function of temperature, and the complex modulus $\left(G^{*}\right)$ and loss tangent $(\tan \delta)$ were calculated as $\left|G^{*}\right|^{2}=\left|G^{\prime}\right|^{2}+\left|G^{\prime \prime}\right|^{2}$ and $\tan \delta=G^{\prime \prime} / G^{\prime}$ respectively. Temperature sweeps at constant frequency of $1 \mathrm{~Hz}$ were carried out inside the linear viscoelastic region (LVR), in a temperature range from 25 up to $170^{\circ} \mathrm{C}$ by applying a heating ramp of $2^{\circ} \mathrm{C} / \mathrm{min}$.

\subsubsection{Water uptake}

A simple test was used to determine water absorption capacity of all samples after their immersion in $50 \mathrm{~mL}$ distilled water at room temperature ( 2 and $48 \mathrm{~h}$ ). Water on the surface of the samples was removed, and the samples were weighed again $\left(W_{1}\right)$. The remaining water, containing plasticizers and soluble proteins, was dried in order to quantify the weight of soluble matter $\left(W_{\text {sol }}\right)$. Water absorption $(A b)$ was calculated after 2 and $48 \mathrm{~h}$ by using Equation (1):

$A b=\frac{W_{1}-W_{0}+W_{\text {sol }}}{W_{0}}$

where $W_{1}, W_{0}$ and $W_{\text {sol }}$ are the weights of the wet specimen, specimen before swelling and water-soluble residue, respectively.

\subsubsection{X-ray diffraction (XRD)}

A Bruker D8 Advance X-Ray Diffractometer (Bruker, Massachusetts, USA) with a monochromatized $\mathrm{CuK} \alpha$ radiation at $40 \mathrm{kV}$ and $30 \mathrm{~mA}$ was used to carry out $\mathrm{X}$-ray diffraction tests. A scanning range (20) from 2 to $30^{\circ}$ with a step size of $0.05^{\circ}$ and a count time of $15 \mathrm{~s}$ per step was applied. Bragg's law was used to calculate the clay gallery separation. 
2.4.6. Transmission electron microscopy (TEM) Specimens for TEM observation were cut from bioplastic and biocomposite blocks at $-120^{\circ} \mathrm{C}$, using a Leica EM UC7 Ultramicrotome (Wetzlar, Germany), equipped with a glass knife, to obtain sections with thickness between 70 and $90 \mathrm{~nm}$. Transmission electron images were taken with a Zeiss Libra 120 microscope, at an acceleration voltage of $80 \mathrm{kV}$.

\subsubsection{Statistical analysis}

At least three replicates of water uptake capacity and DMTA tests or five tensile tests (n) were carried out. Standard deviations were calculated for some selected parameters from water uptake capacity and tensile test. The data were presented as average $(\bar{x}) \pm$ standard deviation $\left.\left[\sum_{\mathrm{n}}\left(x_{\mathrm{n}}-\bar{x}\right)^{2} /(n-1)\right]^{1 / 2}\right)$.

\section{Results and discussion}

\subsection{Mechanical properties}

Figure 1 plots the tensile stress-strain response of the bioplastics and biocomposites studied. All samples exhibited a plastic tensile behaviour after a small elastic deformation. This can be most appreciated from the WGGW-SH system in which the elastic zone is barely noticeable. All of the polymers showed an increase in strength at low strain values, followed by a progressive decrease to a constant stress-strain slope which concluded with the rupture of samples at tensile strength value. The characteristic mechanical properties of bioplastics and biocomposites as obtained from the tensile stress-stain plots are colected in Table 2

As can be noticed from Table 2, the $\mathrm{pH}$ had a significant effect on the mechanical properties of the samples. The WGGW sample, with a pH around 6, showed the highest values for Young's modulus and the tensile strength (31.9 and 4.1 MPa, respectively). On the other hand, a drastic decrease of tensile strength occurred in the samples processed under alkaline conditions (WGGW-SH) although the strain at break was not affected. Finally, in acid conditions (WGGWSA), the strain at break increased considerably despite the reduction of plasticizer (203.8\%).

At $\mathrm{pH}$ 6, the WGGW samples are processed at $\mathrm{pH}$ closer to the isoelectric point of wheat gluten ( $\mathrm{pH}$ of 7.5). The positive charges in the molecule are balanced out by the negative charges at its isoelectric point, resulting in a net charge of zero in the molecular

Table 2. Mechanical properties of nanobiocomposites as a function of the $\mathrm{pH}$.

\begin{tabular}{|l|c|c|c|c|}
\hline \multicolumn{1}{|c|}{ Systems } & $\mathbf{p H}$ & $\begin{array}{c}\text { Young's modulus } \\
\text { [MPa] }\end{array}$ & $\begin{array}{c}\text { Strain at break } \\
\text { [\%] }\end{array}$ & $\begin{array}{c}\text { Tensile strengh } \\
{[\text { MPa] }}\end{array}$ \\
\hline WGGW & 6.1 & $31.9 \pm 3.1$ & $175.4 \pm 21.2$ & $4.1 \pm 0.3$ \\
\hline WGGW-MMT & 6.1 & $27.0 \pm 1.8$ & $135.0 \pm 12.4$ & $3.8 \pm 0.3$ \\
\hline WGGW-SH & 10.8 & $7.7 \pm 0.3$ & $165.1 \pm 15.5$ & $1.8 \pm 0.1$ \\
\hline WGGW-SH-MMT & 10.8 & $14.7 \pm 1.2$ & $136.9 \pm 15.1$ & $2.5 \pm 0.2$ \\
\hline WGGW-SA & 5.4 & $15.7 \pm 1.3$ & $203.8 \pm 18.2$ & $3.0 \pm 0.1$ \\
\hline WGGW-SA-MMT & 5.4 & $19.8 \pm 1.4$ & $150.1 \pm 19.9$ & $2.8 \pm 0.1$ \\
\hline
\end{tabular}

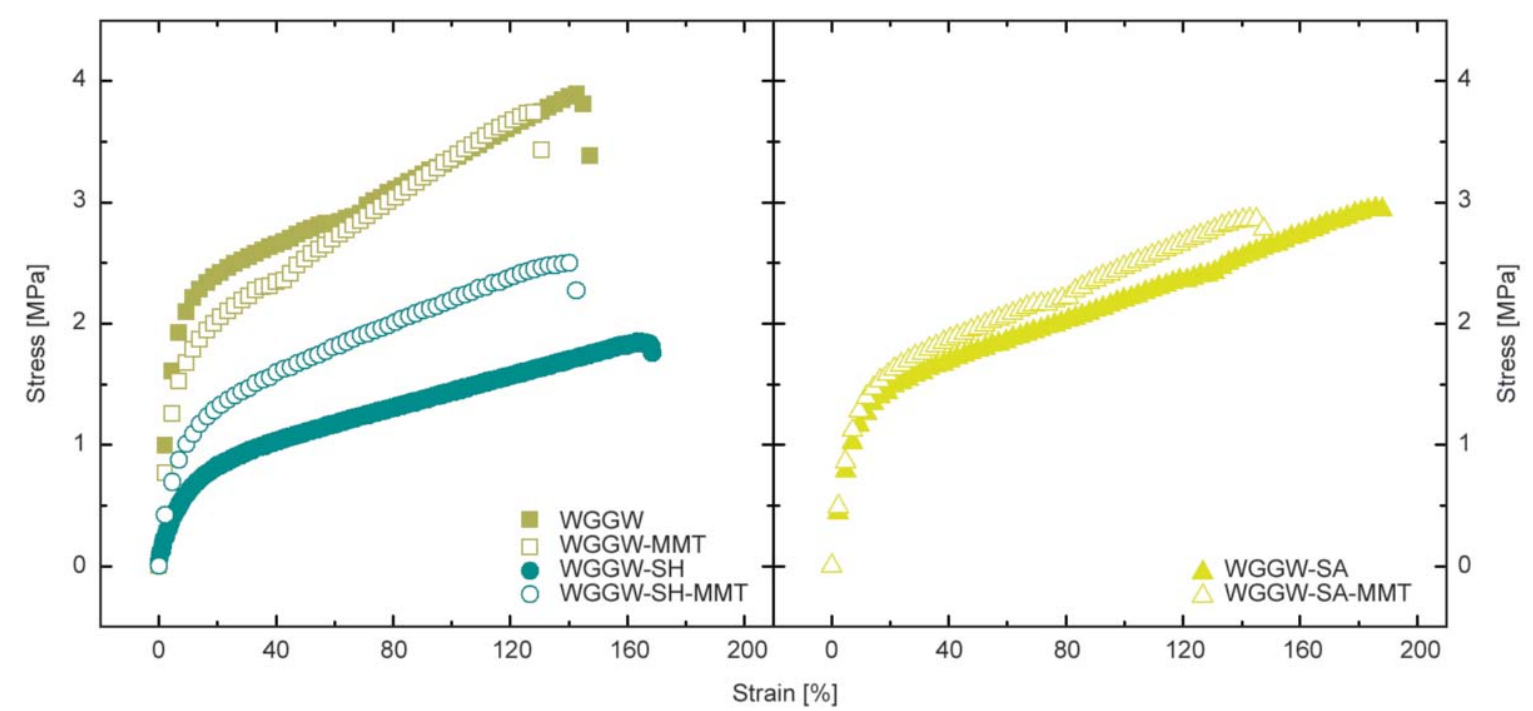

Figure 1. Stress-strain curves for different systems as a function of the $\mathrm{pH}$. 
structure $[22,24-26]$. Thus, at $\mathrm{pH} 6$, the non-charged proteins are able to establish stronger bonds (ionic bonds and covalent bonds such as peptide and disulfide bonds) after thermomechanical processing, which results in higher modulus values (tensile strength, and Young's modulus) if compared to $\mathrm{pH} 5.4$ and 10.8 [27].

During compression-moulding under alkaline conditions, $\mathrm{NaOH}$ induces formation of nondisulphide covalent crosslinks, such as dehydroalanine, lysinoalanine and lanthionine [28]. The resulting intraand intermolecular crosslinks are stable such that, as stated by Jansens et al. [29], replacement of disulphide bonds with other covalent bonds does not apparently affect the material properties of the end products. $\mathrm{NaOH}$ generally accelerates the cross-linking reaction, thus significantly improving Young's modulus, tensile strength, and strain at break. However, an $\mathrm{NaOH}$ content $>0.5 \mathrm{wt} \%$ could cause adverse effects at moulding temperatures as high as $110^{\circ} \mathrm{C}$ [30]. Jansens et al. [29] reported that alkaline conditions may induce protein degradation, likely caused by peptide bond hydrolysis, with the formation of low $M_{\mathrm{W}}$ protein fragments. This could explain the decreased values of Young's modulus and tensile strength obtained for the WGGW-SH samples.

The increase in the strain at break value obtained under acid conditions (WGGW-SA) could be explained by an increased interaction between plasticizer and protein [31]. Conformational changes in the molecular structure of wheat gluten are produced when the $\mathrm{pH}$ is modified from its isoelectric point, generating the movements of the protein chains and allowing a higher sliding of plasticizer through them. In addition to the increase in plasticizing effect, however, the addition of acid prevents the wheat gluten cross-linking, thus accounting for the lower tensile strength and Young's modulus of the WGGW-SA samples. This trend was also observed by Baldwin et al. [32] and Jagadeesh et al. [33] for films containing solely plasticizers, whereas the plasticizer concentration increased, tensile strength was significantly decreased [34].

The effect of introducing layered silicates (MMT) in the wheat gluten matrix of WG-based bioplastics did not exhibit increases in the mechanical properties. This may be caused by poor clay dispersion which strongly depends on the protein-clay interaction. At $\mathrm{pH}$ 6, close to the isoelectric point of wheat gluten, the net charge of the molecule is zero and the protein-clay compatibility decreased giving rise to the agglomeration of the nanoparticles as is shown in Figure 6b. As is apparent from Figure 1, only the WGGW-SH-MMT system presents higher Young's modulus and tensile strength values, if compared to its counterpart without MMT (WGGW-SH).

Since unmodified MMT is hydrophilic and negatively charged, it was supposed to be naturally compatible with the hydrophilic and positively charged wheat gluten matrix and, thus, appeared suitable for nanocomposite preparation. However, the very low frequency of charged groups on the gluten proteins combined with a rather high frequency of non-polar side chains [2] indicated that the compatibility between protein and clay might be improved by modifying

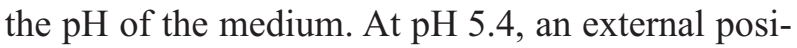
tive charge balance in the protein chain should take place as result of the acid medium, allowing its interaction with the clay nanoparticles, which are characterized by an external negative charge inside the clay platelet [35]. However, for the said sample (WGGW-SA-MMT), only a slight increase on the Young's modulus was actually obtained (from 15.7 to 19.8 MPa), indicating a small degree of interaction between positively charged gluten molecules and negatively charged nanoclay. Conversely, great differences in the mechanical properties of bioplastics were found when nanoparticles were dispersed in alkaline medium (WGGW-SH-MMT). Young's modulus significantly increased when the reinforcements were added to the bioplastic, possibly as a consequence of the exfoliation of nanoclays in the polymeric matrix. This is consistent with TEM results which show the dispersion of the clay as discussed later (Figure 6). $\mathrm{Na}^{+}$cations are located into the inter-layer space, which are externally exposed when the exfoliation layers is produced. In this way, a strong interaction between $\mathrm{Na}^{+}$cations of exfoliated nanoparticles and the external negative charge of protein in alkaline conditions could be produced, giving rise to an increase of Young's modulus of bioplastics (from 7.7 to $14.7 \mathrm{MPa}$ ). A better understanding of the internal chemical interactions between protein and nanoclays as a function of $\mathrm{pH}$ can be seen in Figure 2.

Noteworthy is that the strain at break value of all samples decreased with the presence of the nanoclays (see Table 2). The hydrophilic character of MMT might favour the establishment of hydrogen bonds with the plasticizer (glycerol), this latter becoming less available for the plasticization of the wheat 
gluten matrix. A decrease in plasticizer content has already been found to increase tensile strength values [36]. Thus, the macromolecular structure of wheat gluten-based materials can be affected by the nature of the reinforcing filler, and more precisely, by the interactions that might be established between the different constituents [2].
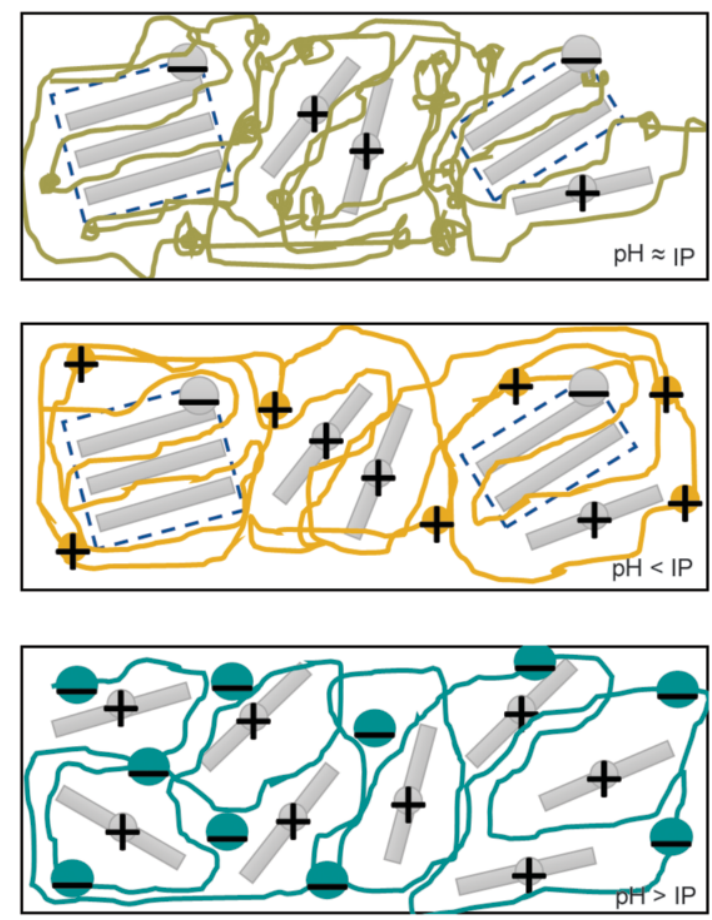

Figure 2. Chemical behaviour of protein and MMT as a function of $\mathrm{pH}$.

\subsection{Water uptake}

The water absorption capacity of the bioplastics and biocomposites can be seen on Table 3 and Figure 3 as a function of $\mathrm{pH}$. As shown, the water absorption obtained at both pH 5.40 and 10.8 was higher than that obtained at $\mathrm{pH}$ 6.1. That is, the water absorption capacity was enhanced when the $\mathrm{pH}$ was far from the isoelectric point. These results indicate that the presence of charges at the protein surfaces must play an important role in their water uptake capability, with the best performance being obtained under the strongly alkaline conditions; the system at $\mathrm{pH} 10.8$ showed a water uptake of $102 \%$ after $48 \mathrm{~h}$ of immersion.

Table 3 also shows that the presence of MMT increased water resistance in all of the biocomposites if compared to their counterparts without MMT. Most markedly, a reduction of the liquid water uptake of $10 \mathrm{wt} \%$ occurred for the biocomposite processed at pH 6.1; that is, a minimum solubility of protein was

Table 3. Water absorption capacity of samples.

\begin{tabular}{|l|r|c|c|}
\hline \multirow{2}{*}{\multicolumn{1}{c|}{ Systems }} & \multirow{2}{*}{$\mathbf{p H}$} & \multicolumn{2}{c|}{$\begin{array}{c}\text { Abs } \\
\text { [wt\%] }\end{array}$} \\
\cline { 3 - 4 } & & $\mathbf{2 ~ h}$ & $\mathbf{4 8} \mathbf{~ h}$ \\
\hline WGGW & 6.1 & $42.8 \pm 1.1$ & $62.7 \pm 3.2$ \\
\hline WGGW-MMT & 6.1 & $34.3 \pm 0.8$ & $43.2 \pm 1.3$ \\
\hline WGGW-SH & 10.8 & $74.8 \pm 2.3$ & $102.0 \pm 5.3$ \\
\hline WGGW-SH-MMT & 10.8 & $69.9 \pm 1.8$ & $91.9 \pm 4.9$ \\
\hline WGGW-SA & 5.4 & $49.0 \pm 0.8$ & $69.8 \pm 0.5$ \\
\hline WGGW-SA-MMT & 5.4 & $50.4 \pm 0.8$ & $68.5 \pm 0.8$ \\
\hline
\end{tabular}

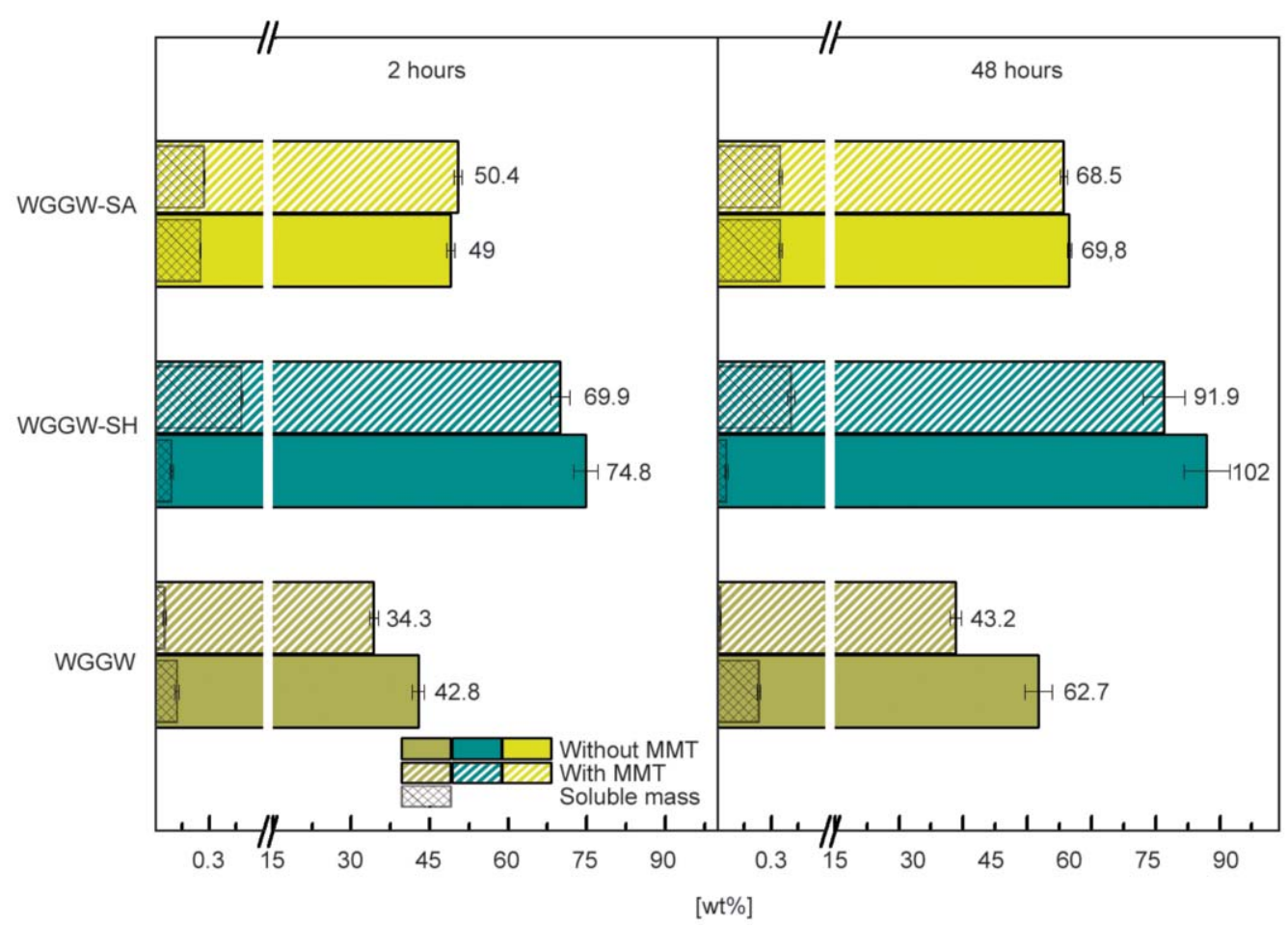

Figure 3. Water absorption capacity of bioplastics and nanobiocomposites. 
achieved at their isoelectric point, increasing as the $\mathrm{pH}$ value is distanced [22]. Thus, aggregation of the protein molecules close to the isoelectric $\mathrm{pH}$ in WGGW sample was favoured, hampering water penetration in the system and reaching the lowest water absorption values.

On the contrary, the presence of MMT in the WGGW-SA and WGGW-SH samples did not impact the water sensitivity since equilibrium parameters were not significantly different from values obtained for the neat matrix (Table 3). However, the presence of MMT in the WGGW-SH matrix significantly increased soluble mass (Figure 3) and altered the properties of the gluten-based biocomposite, possibly because of the protein degradation previously reported.

\subsection{Thermomechanical behaviour}

Figure 4 depicts the complex modulus $\left|G^{*}\right|$ and loss tangent $(\tan \delta)$ as a function of temperature, obtained from the DMA experiments of the bioplastics and biocomposites. As can be noticed, higher complex modulus values were obtained in those samples at pH 6.1 (control WGGW sample) and $\mathrm{pH} 5.4$ (WGGW-SA sample). For these samples, $\left|G^{*}\right|$ decreased with increasing temperature up to $120^{\circ} \mathrm{C}$, followed by a short temperature interval where $\left|G^{*}\right|$ levels off, thus extending this rubbery-like plateau from
120 up to $160^{\circ} \mathrm{C}$. Note that the acid addition clearly resulted in an extension of the plateau region in the WGGW-SA and WGGW-SA-MMT samples For protein based systems, this plateau region has been attributed to a situation that falls between a temporary entangled network and covalent crosslinking [37], as hydrophobic interactions usually act not at a point on the chain as covalent crosslinks do, but involve more extended 'junction zones'. Thus, an extension of this region - as was obtained under acid conditions - results in decreased susceptibility of the bioplastic to temperature. This effect became more marked with increasing acid content due to the increased number of sites available for interactions amongst the chains, probably by inhibiting protein aggregation, as has been previously reported [38].

The values of $\left|G^{*}\right|$ were lower for the bioplastic at $10.8 \mathrm{pH}$ (WGGW-SH) than for the control in the whole temperature range studied. In this case, a lower temperature $\left(80^{\circ} \mathrm{C}\right)$ was needed for starting the plateau region, which was extended from 80 up to $110^{\circ} \mathrm{C}$, followed by a high-temperature decrease of $\left|G^{*}\right|$. Low $M_{\mathrm{W}}$ fragments and protein denaturation under alkaline conditions (as discussed in Section 3.1) resulted in lower viscoelastic properties of the system.

Figure 4 shows that the addition of nanoclays resulted in an increase in the complex modulus of all the

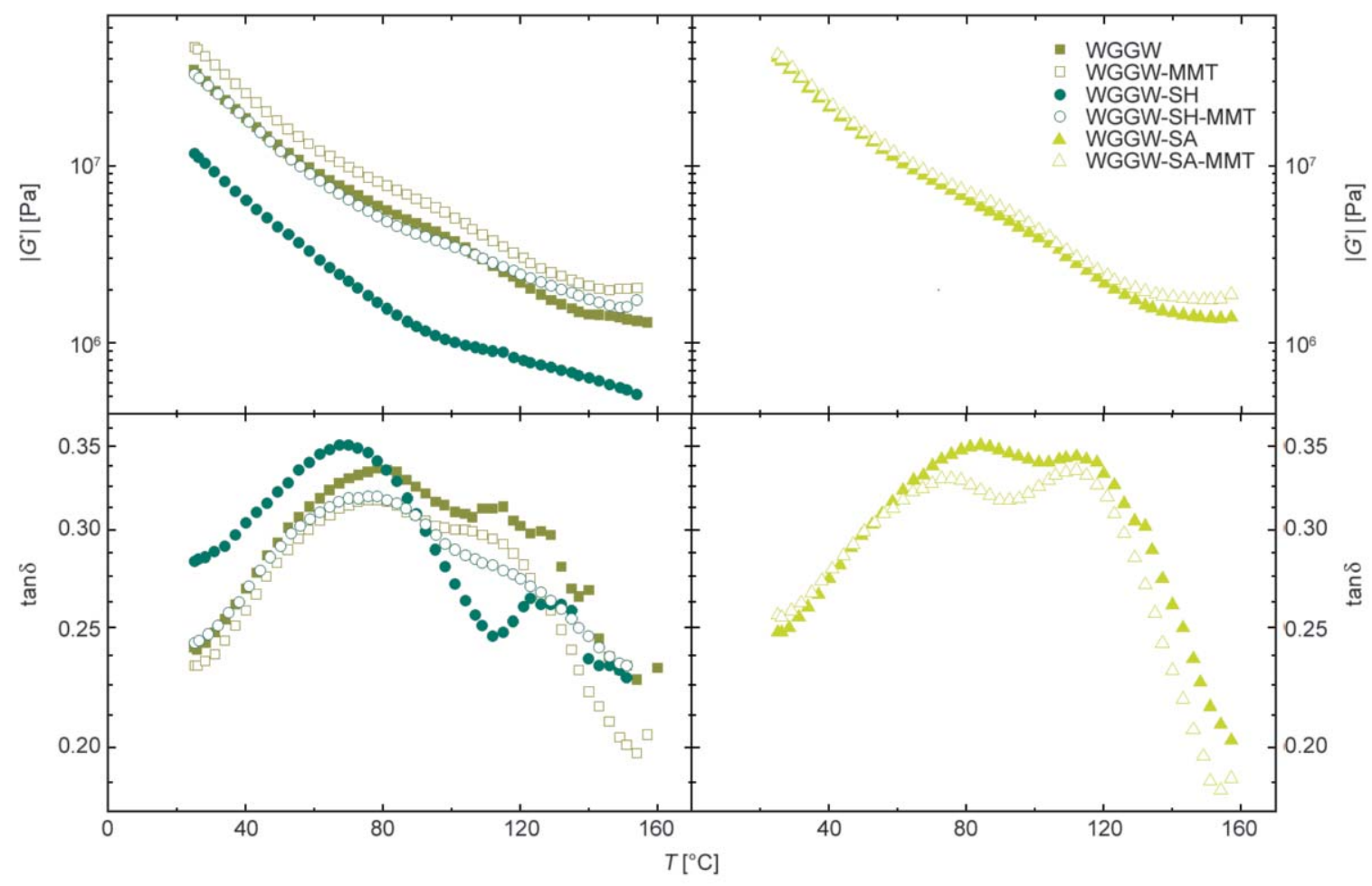

Figure 4. Frecuency dependence of the complex modulus $\left(G^{*}\right)$ and loss tangent $(\tan \delta)$ for bioplastics and nanobiocomposites as a function of the $\mathrm{pH}$. 


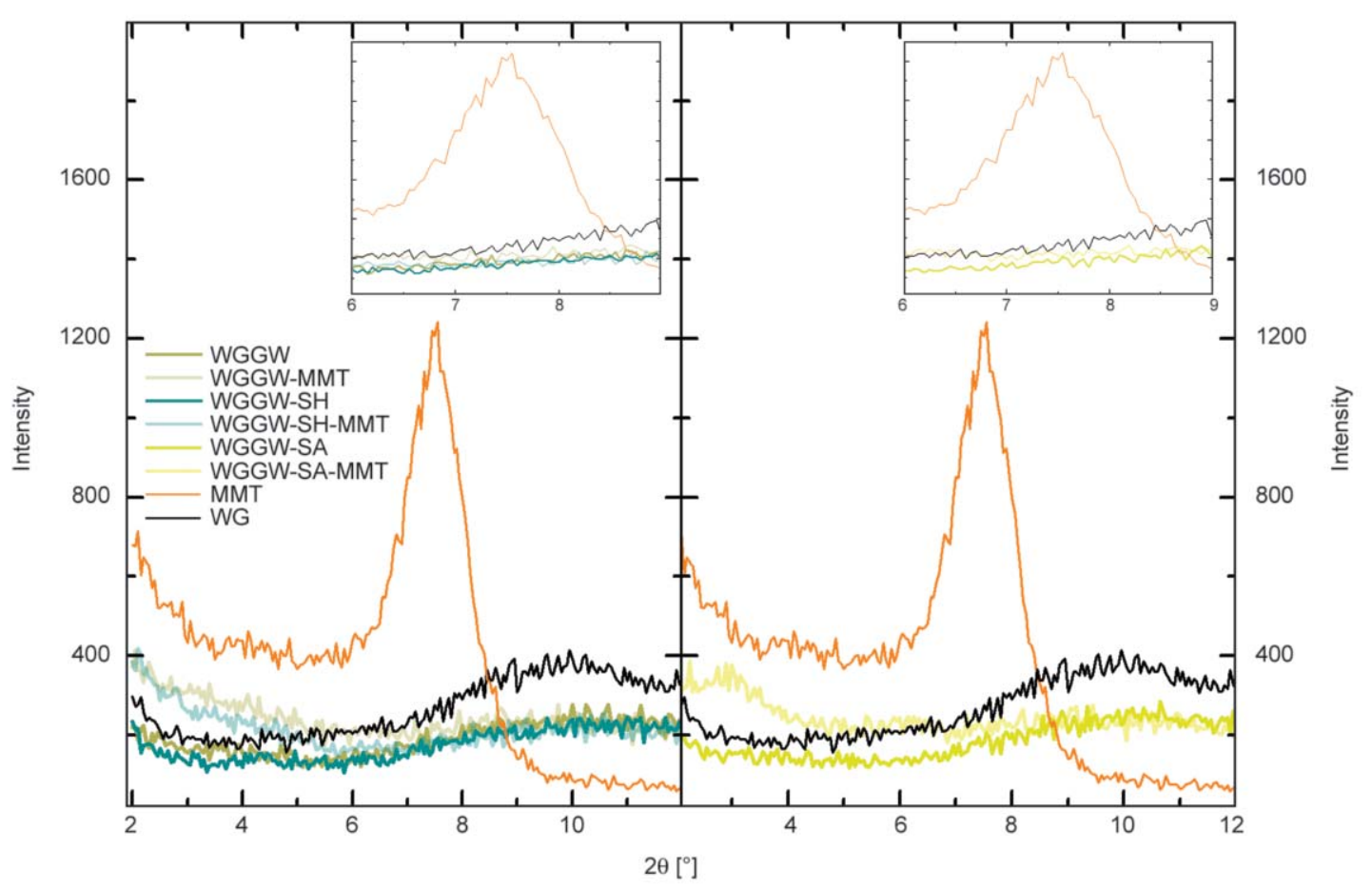

Figure 5. X-ray diffraction patterns.

systems. Nevertheless, the presence of reinforcements in the alkaline system allowed obtaining the greatest increase of complex modulus values as result of a better interfacial interaction between polymeric matrix and exfoliated nanoparticles (see Figure 5). On the contrary, MMT intercalates into the matrix at 5.4 and $6.1 \mathrm{pH}$, which does not induce an enhancement in viscoelastic properties, presenting small to no differences in the complex modulus.

Finally, from the loss tangent curves presented in Figure 4, the glass transition temperatures may be identified. As may be observed, two well defined peaks were obtained for all the samples. The first peak, $T_{\mathrm{g} 1}$, located close to $70^{\circ} \mathrm{C}$ was attributed to a glass transition temperature of the plasticized wheat gluten $[39,40]$, whereas the second peak, $T_{\mathrm{g} 2}$, at around $130^{\circ} \mathrm{C}$, would be mainly related to an internal rearrangement of the material. The system prepared in alkaline conditions (WGGW-SH) showed a lower $T_{\mathrm{g} 1}\left(67^{\circ} \mathrm{C}\right)$ and a higher $T_{\mathrm{g} 2}\left(125^{\circ} \mathrm{C}\right)$ compared with the rest of systems (around 80 and $115^{\circ} \mathrm{C}$, respectively), likely due to a rearrangement of the material at a higher temperature through interfacial interactions. A significant shift of $T_{\mathrm{g}}$ values toward higher temperatures for biocomposite at $10.8 \mathrm{pH}$ was noted, indicating that the presence of MMT strongly restricted the protein chain mobility. Overall, these results show that the presence of nanoclays can affect the glass transition temperature of wheat gluten-based materials, with the biggest changes occurring in alkaline medium systems.

\subsection{Microstructural analysis}

The morphology of wheat gluten-based materials was evaluated using XRD analysis (Figure 5) combined with TEM observations (Figure 6). To go further in this investigation, characterization of the nanostructure by TEM and XRD appeared essential in order to support all the hypotheses proposed above.

The degree of clay dispersion is usually characterized by XRD. Figure 5 shows the XRD patterns for the original clay (MMT) and the WGGW-MMT nanocomposites at different $\mathrm{pH}$. As can be observed, the MMT clay layers showed a strong peak at $7.5^{\circ}(2 \theta)$, giving a $\mathrm{d}_{001}$ spacing of $11.70 \mathrm{~nm}$ which is associated with the spacing between the silica layers that constitute the clay structure. On the other hand, the XRD patterns of the bioplastic and biocomposites changed dramatically in comparison with montmorillonite clay, with no sharp peaks being observed. In fact, the peak at $7.5^{\circ}(2 \theta)$ disappeared when the nanoparticles were introduced into the wheat gluten bioplastics.

In general, the absence of diffraction peaks in the XRD pattern can be attributed to two possible reasons: (a) exfoliated structure and (b) partially exfoliated-intercalated structure. In either instance, this exfoliation confirms the existence of a high dispersion 

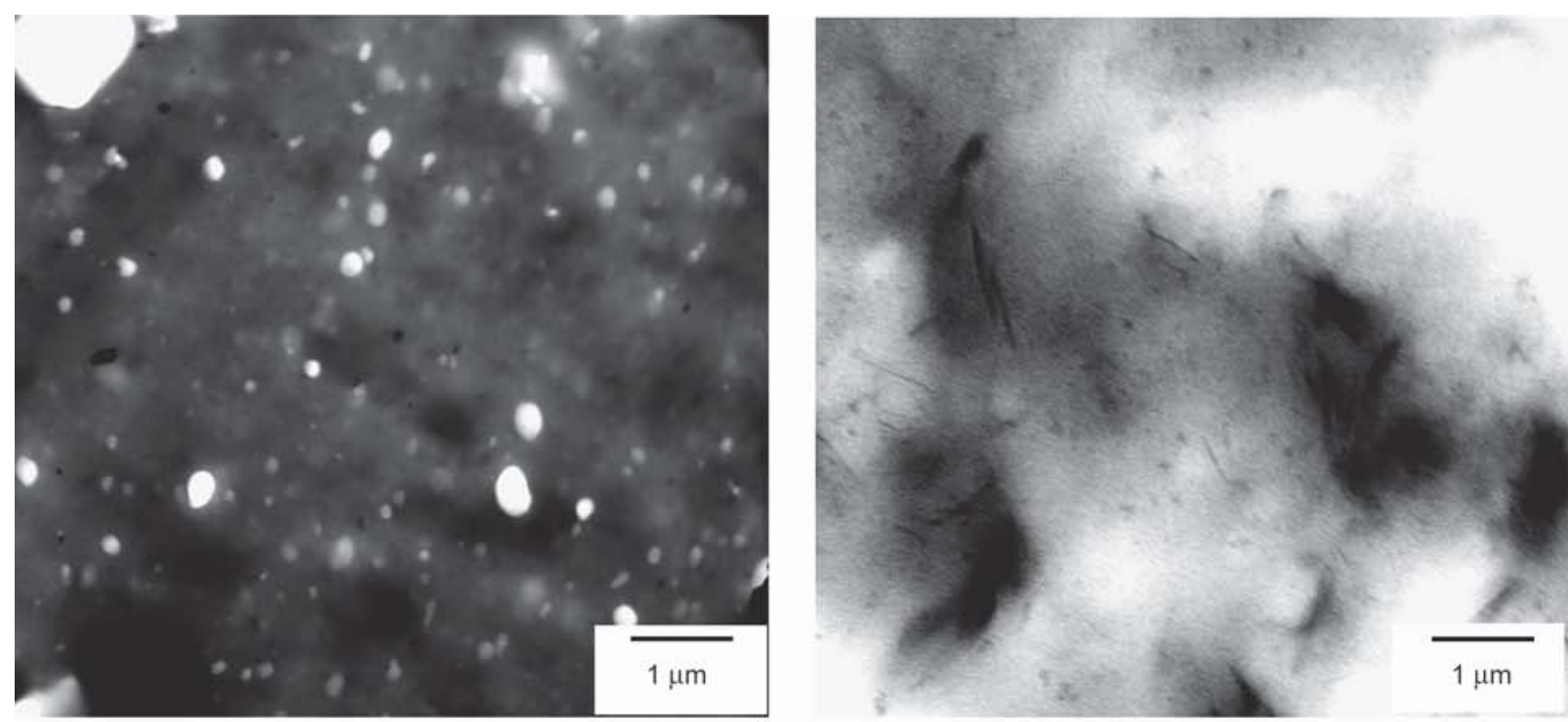

a)

b)
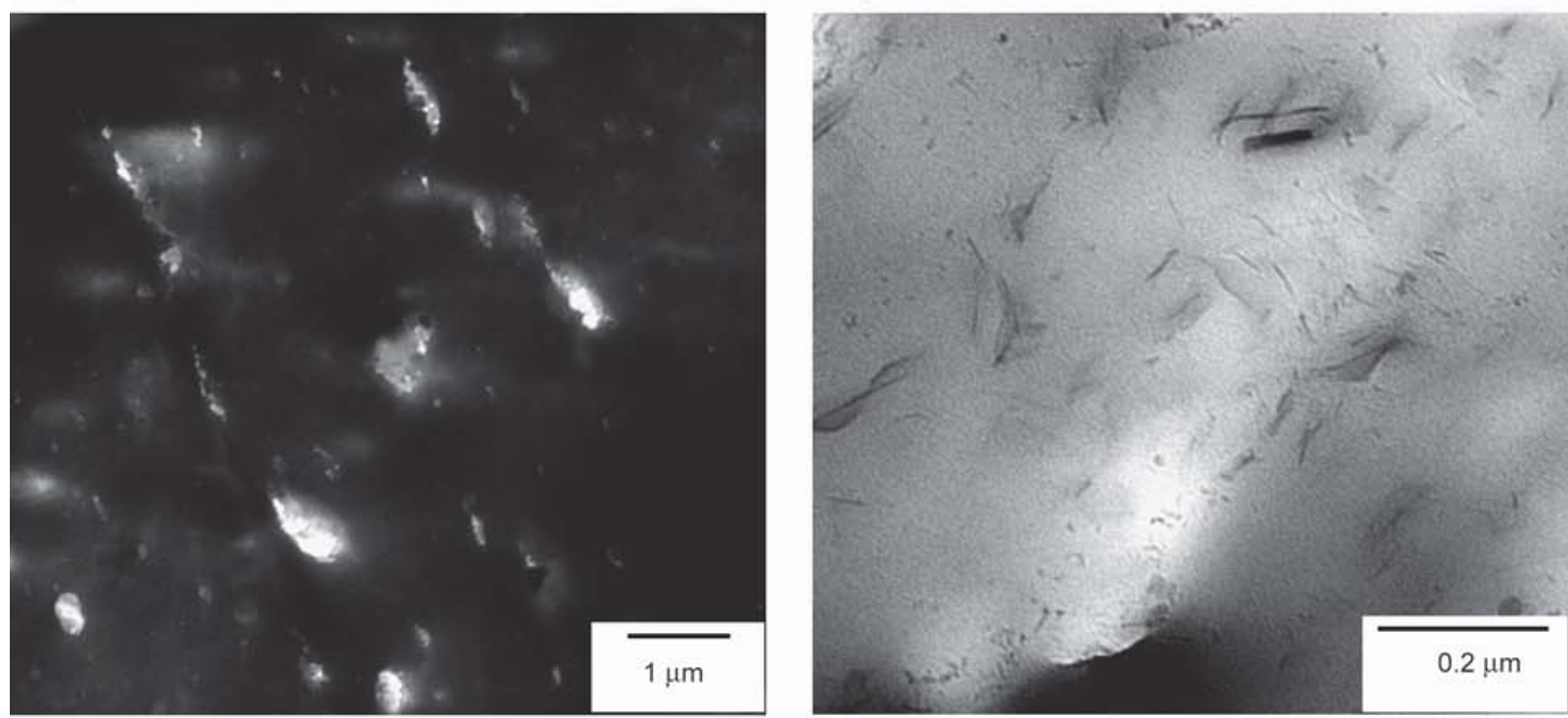

c)

d)

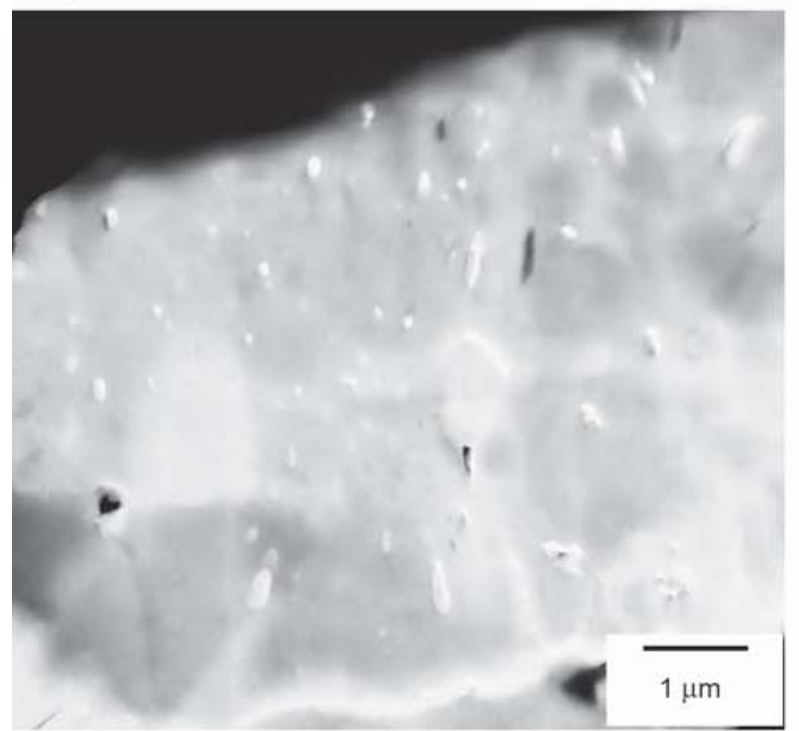

e)

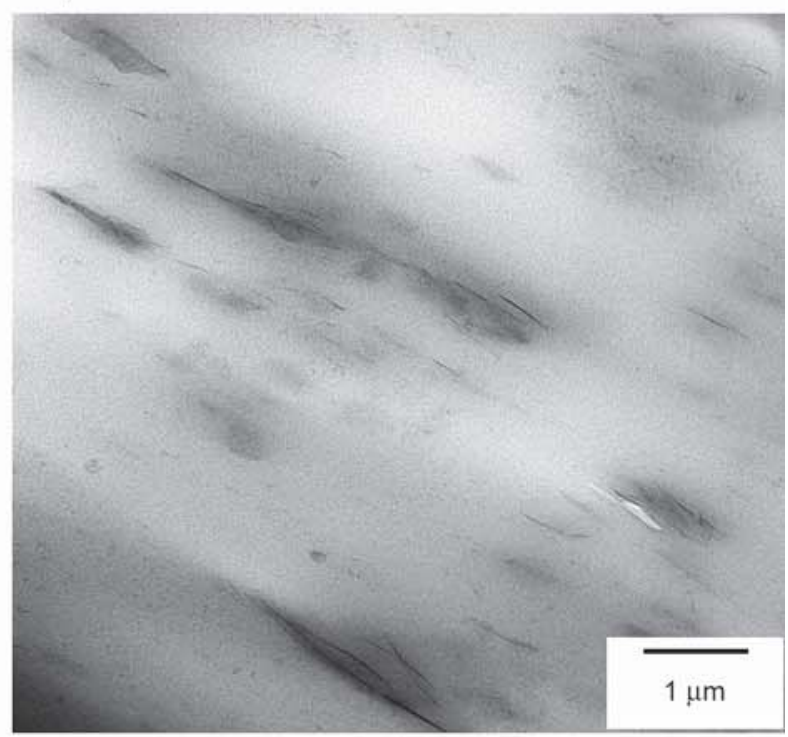

f)

Figure 6. TEM images of (a) WGGW, (c) WGGW-SH and (e) WGGW-SA samples without nanoclays, and the corresponding systems with MMT (b), (d) and (f), respectively. 
degree of nanoclays within the polymeric matrix of all systems. However, slight differences can be noticeable. Diffraction patterns $\left(7.5^{\circ}\right)$ of bioplastics at $10.8 \mathrm{pH}$ (WGGW-SH) showed no differences compared with their biocomposites (WGGW-SH-MMT), which might be a confirmation of the total exfoliation of reinforcement in the polymeric matrix.

Figure 6 shows that the TEM images of the wheat gluten bioplastics are clearly different from their associated biocomposites. All of the bioplastics possessed pores associated with aggregated proteins (Figure $6 \mathrm{a}, 6 \mathrm{c}, 6 \mathrm{e})$. These pores could also be ascribed to combined phenomena including air incorporation during the extrusion process and/or a rapid water evaporation in the die, resulting in material expansion [2]. However, this is unlikely for these wheat gluten bioplastics given that the same pores are not present in TEM images of the samples containing clays in their formulation (Figure 6b, 6d, 6f).

From the TEM images of the wheat gluten bioplastics, it can be seen that the WGGW sample (Figure 6a) possessed a larger number of pores, which would result in a coarser and expectedly less rigid structure than that found at the other $\mathrm{pH}$ values (10.8 and 5.40) (Figure $6 \mathrm{c}$ and 6e, respectively). This behaviour may be related to its proximity to the protein isoelectric point, at which the protein molecules are slightly more aggregated, with lesser molecular interactions.

On the other hand, the TEM images of biocomposites at different $\mathrm{pH}$ (Figure 6b, 6d, 6f), show that the introduction of nanoparticles involves noticeable structural changes. Figure $6 \mathrm{~d}$ shows that most of the clay layers were disorderly dispersed within the protein matrix at basic $\mathrm{pH}$ (WGGW-SH-MMT). The delaminated silicate lamellas in the bioplastic are further randomized, disordered and shifted during the extruding process. This indicates strong mixing of the nanoparticles with the negatively charged protein molecules. As presented in Section 3.1, this likely results from strong ionic interactions between the $\mathrm{Na}^{+}$ ions of the nanoclay and the negative charges on the protein under the strongly basic conditions. In the case of the sample WGGW-SA-MMT (Figure 6f) it was apparent that the clay layers were orientated and presented an intercalated-exfoliated dispersion. This is consistent with the small degree of interaction expected between the positively charged gluten molecules and the negatively charged nanoclay previously discussed in Section 3.1. The system WGGW-MMT also displayed an intercalated-exfoliated dispersion; however, we can observe in Figure 6b stack-like structures, which are consistent with even less interaction between the uncharged gluten molecules and the nanoclay particles; recall from Section 3.1 that at $\mathrm{pH} 6$, close to the isoelectric point of wheat gluten, the net charge of the molecule is zero. Furthermore, at this $\mathrm{pH}$ the protein is most crosslinked, further restricting ability of the nanoparticles to intercalate into the protein compared to the systems at other $\mathrm{pH}$. This results in agglomeration of the nanoparticles with each other, as is shown in Figure 6b.

In general, the effect of $\mathrm{pH}$ value on clay dispersion is subtle but can be directly visualized by comparing TEM images and XRD patterns of biocomposites.

\section{Conclusions}

Bioplastics and biocomposites were successfully prepared by using an extrusion process at low temperatures. The processing $\mathrm{pH}$ exerted a significant influence on the properties of these materials, with a reduction in the plasticizer/protein weight ratio being necessary when acid conditions were used. An increase in the mechanical and rheological properties of the bioplastics occurred at $\mathrm{pH}$ close to the isoelectric point of wheat gluten $(\mathrm{pH}=7.5)$, which were drastically reduced in alkaline conditions. However, a good interaction between nanoclay and protein was reached on alkaline biocomposites $(\mathrm{pH}>10)$, giving rise to high exfoliation of reinforcements inside polymeric matrix and thoroughly improving the mechanical and rheological properties. The presence of intercalated-exfoliated nanoparticles structures took place in the rest of the systems. Nanoclay dispersion can be confirmed by means of XDR patterns and TEM images. Rheological response for all bioplastics showed two glass transition, 65 and $130^{\circ} \mathrm{C}$, which were raised and overlapped with the use of nanoparticles at alkaline $\mathrm{pH}$, resulting in a better dispersion of their compounds. Finally, the water absorption values indicate that the clay platelets effectively acted as geometrical obstacles in the wheat gluten matrix. Overall, we have presented a method for the preparation of biocomposites via $\mathrm{pH}$-induced nanoclay dispersion. Our method allows for the use of the conventional equipment to obtain these biocomposites, thus reducing the barriers from lab to commercial scale up for the production of synthetic biodegradable composites from renewable sources. 


\section{Acknowledgements}

This work is part of a research project sponsored by 'Ministerio de Economía y Competitividad' from Spanish Government (Ref. CTQ2015-71164-P). The authors gratefully acknowledge their financial support. The authors also acknowledge to the Microscopy Service (CITIUS-Universidad de Sevilla) for providing full access and assistance to the Libra 120 equipment. In addition, the authors gratefully acknowledge Asunción Fernández for her technical support in the Microscopy Service.

\section{References}

[1] Domenek S., Feuilloley P., Gratraud J., Morel M-H., Guilbert S.: Biodegradability of wheat gluten based bioplastics. Chemosphere, 54, 551-559 (2004). https://doi.org/10.1016/S0045-6535(03)00760-4

[2] Chevillard A., Angellier-Coussy H., Cuq B., Guillard V., César G., Gontard N., Gastaldi E.: How the biodegradability of wheat gluten-based agromaterial can be modulated by adding nanoclays. Polymer Degradation and Stability, 96, 2088-2097 (2011).

https://doi.org/10.1016/j.polymdegradstab.2011.09.024

[3] Redl A., Morel M. H., Bonicel J., Vergnes B., Guilbert S.: Extrusion of wheat gluten plasticized with glycerol: Influence of process conditions on flow behavior, rheological properties, and molecular size distribution. Cereal Chemistry, 76, 361-370 (1999).

https://doi.org/10.1094/CCHEM.1999.76.3.361

[4] Angellier-Coussy H., Guillard V., Guillaume C., Gontard N.: Wheat gluten (WG)-based materials for food packaging. in 'Multifunctional and nanoreinforced polymers for food packaging' (ed.: Lagarón J-M.) Woodhead, 649-668 (2011).

https://doi.org/10.1533/9780857092786.4.649

[5] Thammahiwes S., Riyajan S-A., Kaewtatip K.: Preparation and properties of wheat gluten based bioplastics with fish scale. Journal of Cereal Science, 75, 186-191 (2017).

https://doi.org/10.1016/j.jcs.2017.04.003

[6] Cuq B., Gontard N., Guilbert S.: Proteins as agricultural polymers for packaging production. Cereal Chemistry, 75, 1-9 (1998). https://doi.org/10.1094/CCHEM.1998.75.1.1

[7] Lagrain B., Goderis B., Brijs K., Delcour J. A.: Molecular basis of processing wheat gluten toward biobased materials. Biomacromolecules, 11, 533-541 (2010). https://doi.org/10.1021/bm100008p

[8] Dicharry R. M., Ye P., Saha G., Waxman E., Asandei A. D., Parnas R. S.: Wheat gluten-thiolated poly(vinyl alcohol) blends with improved mechanical properties. Biomacromolecules, 7, 2837-2844 (2006).

https://doi.org/10.1021/bm060432n

[9] Gómez-Heincke D., Martínez I., Stading M., Gallegos C., Partal P.: Improvement of mechanical and water absorption properties of plant protein based bioplastics. Food Hydrocolloids, 73, 21-29 (2017).

https://doi.org/10.1016/j.foodhyd.2017.06.022
[10] Diañez I., Martínez I., Partal P.: Synergistic effect of combined nanoparticles to elaborate exfoliated eggwhite protein-based nanobiocomposites. Composites Part B: Engineering, 88, 36-43 (2016). https://doi.org/10.1016/j.compositesb.2015.10.034

[11] Ruiz-Hitzky E., Darder M., Aranda P.: Functional biopolymer nanocomposites based on layered solids. Journal of Materials Chemistry, 15, 3650-3662 (2005). https://doi.org/10.1039/b505640n

[12] Giannelis E.: Polymer layered silicate nanocomposites. Advanced materials, 8, 29-35 (1996). https://doi.org/10.1002/adma.19960080104

[13] Darder M., Aranda P., Ruiz-Hitzky E.: Bionanocomposites: A new concept of ecological, bioinspired, and functional hybrid materials. Advanced Materials, 19, 1309-1319 (2007). https://doi.org/10.1002/adma.200602328

[14] Bordes P., Pollet E., Avérous L.: Nano-biocomposites: Biodegradable polyester/nanoclay systems. Progress in Polymer Science, 34, 125-155 (2009). https://doi.org/10.1016/j.progpolymsci.2008.10.002

[15] Alexandre M., Dubois P.: Polymer-layered silicate nanocomposites: Preparation, properties and uses of a new class of materials. Materials Science and Engineering R: Reports, 28, 1-63 (2000).

https://doi.org/10.1016/S0927-796X(00)00012-7

[16] Bharadwaj R. K.: Modeling the barrier properties of polymer-layered silicate nanocomposites. Macromolecules, 34, 9189-9192 (2001).

https://doi.org/10.1021/MA010780B

[17] Sinha Ray S., Yamada K., Okamoto M., Ueda K.: New polylactide-layered silicate nanocomposites. 2. Concurrent improvements of material properties, biodegradability and melt rheology. Polymer, 44, 857-866 (2003). https://doi.org/10.1016/S0032-3861(02)00818-2

[18] Bourny V., Perez-Puyana V., Felix M., Romero A., Guerrero A.: Evaluation of the injection moulding conditions in soy/nanoclay based composites. European Polymer Journal, 95, 539-546 (2017). https://doi.org/10.1016/j.eurpolymj.2017.08.036

[19] Chivrac F., Pollet E., Avérous L.: Progress in nano-biocomposites based on polysaccharides and nanoclays. Materials Science and Engineering R: Reports, 67, 1-17 (2009). https://doi.org/10.1016/j.mser.2009.09.002

[20] Hári J., Horváth F., Móczó J., Renner K., Pukánszky B.: Competitive interactions, structure and properties in polymer/layered silicate nanocomposites. Express Polymer Letters, 11, 479-492 (2017). https://doi.org/10.3144/expresspolymlett.2017.45

[21] Rombouts I., Lagrain B., Delcour J. A., Türe H., Hedenqvist M. S., Johansson E., Kuktaite R.: Crosslinks in wheat gluten films with hexagonal close-packed protein structures. Industrial Crops and Products, 51, 229-235 (2013). https://doi.org/10.1016/j.indcrop.2013.08.077 
[22] Wihodo M., Moraru C. I.: Physical and chemical methods used to enhance the structure and mechanical properties of protein films: A review. Journal of Food Engineering, 114, 292-302 (2013).

https://doi.org/10.1016/j.jfoodeng.2012.08.021

[23] Zink J., Wyrobnik T., Prinz T., Schmid M.: Physical, chemical and biochemical modifications of proteinbased films and coatings: An extensive review. International Journal of Molecular Sciences, 17, 1376/11376/45 (2016). https://doi.org/10.3390/ijms17091376

[24] Shiku Y., Hamaguchi P. Y., Tanaka M.: Effect of pH on the preparation of edible films based on fish myofibrillar proteins. Fisheries Science, 69, 1026-1032 (2003). https://doi.org/10.1046/j.1444-2906.2003.00722.x

[25] Bonner P. L.: Protein purification. Taylor and Francis, New York (2007).

[26] Gennadios A., Brandenburg A. H., Weller C. L., Testin R. F.: Effect of $\mathrm{pH}$ on properties of wheat gluten and soy protein isolate films. Journal of Agricultural and Food Chemistry, 41, 1835-1839 (1993).

https://doi.org/10.1021/jf00035a006

[27] Zárate-Ramírez L. S., Romero A., Bengoechea C., Partal P., Guerrero A.: Thermo-mechanical and hydrophilic properties of polysaccharide/gluten-based bioplastics. Carbohydrate Polymers, 112, 24-31 (2014). https://doi.org/10.1016/j.carbpol.2014.05.055

[28] Gerrard J. A., Brown P. K.: Protein cross-linking in food: Mechanisms, consequences, applications. International Congress Series, 1245, 211-215 (2002).

https://doi.org/10.1016/S0531-5131(02)00910-X

[29] Jansens K. J. A., Lagrain B., Brijs K., Goderis B., Smet M., Delcour J. A.: Impact of acid and alkaline pretreatments on the molecular network of wheat gluten and on the mechanical properties of compression-molded glassy wheat gluten bioplastics. Journal of Agricultural and Food Chemistry, 61, 9393-9400 (2013). https://doi.org/10.1021/jf403156c

[30] Zhang Q., Song Y., Zheng Q.: Influences of acid and alkali on mechanical properties of compression-molded gluten bioplastics. Cereal Chemistry Journal, 85, 379383 (2008).

https://doi.org/10.1094/CCHEM-85-3-0379

[31] Blanco-Pascual N., Fernández-Martín F., Montero M. P.: Effect of different protein extracts from Dosidicus gigas muscle co-products on edible films development. Food Hydrocolloids, 33, 118-131 (2013).

https://doi.org/10.1016/j.foodhyd.2013.02.019
[32] Baldwin E. A., Hagenmaier R., Bai J., Krochta J. M.: Edible coatings and films to improve food quality. CRC Press, Boca Raton (1994).

[33] Jagadeesh D., Jeevan Prasad Reddy D., Varada Rajulu A.: Preparation and properties of biodegradable films from wheat protein isolate. Journal of Polymers and the Environment, 19, 248-253 (2011).

https://doi.org/10.1007/s10924-010-0271-3

[34] Hager A-S., Vallons K. J. R., Arendt E. K.: Influence of gallic acid and tannic acid on the mechanical and barrier properties of wheat gluten films. Journal of Agricultural and Food Chemistry, 60, 6157-6163 (2012). https://doi.org/10.1021/jf300983m

[35] Nagarajan M., Benjakul S., Prodpran T., Songtipya P.: Effects of $\mathrm{pHs}$ on properties of bio-nanocomposite based on tilapia skin gelatin and Cloisite $\mathrm{Na}^{+}$. International Journal of Biological Macromolecules, 75, 388397 (2015).

https://doi.org/10.1016/j.ijbiomac.2015.01.034

[36] Angellier-Coussy H., Torres-Giner S., Morel M-H., Gontard N., Gastaldi E.: Functional properties of thermoformed wheat gluten/montmorillonite materials with respect to formulation and processing conditions. Journal of Applied Polymer Science, 107, 487-496 (2008). https://doi.org/10.1002/app.27108

[37] Ross-Murphy S. B.: Structure-property relationships in food biopolymer gels and solutions. Journal of Rheology, 39, 1451-1463 (1995).

https://doi.org/10.1122/1.550610

[38] Martínez I., Partal P., García-Morales M., Guerrero A., Gallegos C.: Development of protein-based bioplastics with antimicrobial activity by thermo-mechanical processing. Journal of Food Engineering, 117, 247-254 (2013). https://doi.org/10.1016/j.jfoodeng.2013.02.014

[39] Jerez A., Partal P., Martínez I., Gallegos C., Guerrero A.: Protein-based bioplastics: Effect of thermo-mechanical processing. Rheologica Acta, 46, 711-720 (2007). https://doi.org/10.1007/s00397-007-0165-Z

[40] Sun S., Song Y., Zheng Q.: Thermo-molded wheat gluten plastics plasticized with glycerol: Effect of molding temperature. Food Hydrocolloids, 22, 1006-1013 (2008).

https://doi.org/10.1016/j.foodhyd.2007.05.012 